\title{
The standard of healthcare accreditation standards: a review of empirical research underpinning their development and impact
}

\author{
David Greenfield ${ }^{* \dagger}$, Marjorie Pawsey ${ }^{\dagger}$, Reece Hinchcliff ${ }^{\dagger}$, Max Moldovan $^{\dagger}$ and Jeffrey Braithwaite ${ }^{\dagger}$
}

\begin{abstract}
Background: Healthcare accreditation standards are advocated as an important means of improving clinical practice and organisational performance. Standard development agencies have documented methodologies to promote open, transparent, inclusive development processes where standards are developed by members. They assert that their methodologies are effective and efficient at producing standards appropriate for the health industry. However, the evidence to support these claims requires scrutiny. The study's purpose was to examine the empirical research that grounds the development methods and application of healthcare accreditation standards.
\end{abstract}

Methods: A multi-method strategy was employed over the period March 2010 to August 2011. Five academic health research databases (Medline, Psych INFO, Embase, Social work abstracts, and CINAHL) were interrogated, the websites of 36 agencies associated with the study topic were investigated, and a snowball search was undertaken. Search criteria included accreditation research studies, in English, addressing standards and their impact. Searching in stage 1 initially selected 9386 abstracts. In stage 2, this selection was refined against the inclusion criteria; empirical studies $(n=2111)$ were identified and refined to a selection of 140 papers with the exclusion of clinical or biomedical and commentary pieces. These were independently reviewed by two researchers and reduced to 13 articles that met the study criteria.

Results: The 13 articles were analysed according to four categories: overall findings; standards development; implementation issues; and impact of standards. Studies have only occurred in the acute care setting, predominately in $2003(n=5)$ and $2009(n=4)$, and in the United States $(n=8)$. A multidisciplinary focus $(n=9)$ and mixed method approach $(n=11)$ are common characteristics. Three interventional studies were identified, with the remaining 10 studies having research designs to investigate clinical or organisational impacts. No study directly examined standards development or other issues associated with their progression. Only one study noted implementation issues, identifying several enablers and barriers. Standards were reported to improve organisational efficiency and staff circumstances. However, the impact on clinical quality was mixed, with both improvements and a lack of measurable effects recorded.

Conclusion: Standards are ubiquitous within healthcare and are generally considered to be an important means by which to improve clinical practice and organisational performance. However, there is a lack of robust empirical evidence examining the development, writing, implementation and impacts of healthcare accreditation standards.

Keywords: Healthcare, Accreditation, Standards, Evidence for use, Narrative literature review

\footnotetext{
* Correspondence: d.greenfield@unsw.edu.au

${ }^{\dagger}$ Equal contributors

Centre for Clinical Governance Research, Australian Institute of Health

Innovation, University of New South Wales, Sydney, New South Wales 2052,

Australia
}

\section{Biomed Central}

(c) 2012 Greenfield et al.; licensee BioMed Central Ltd. This is an Open Access article distributed under the terms of the Creative Commons Attribution License (http://creativecommons.org/licenses/by/2.0), which permits unrestricted use, distribution, and reproduction in any medium, provided the original work is properly cited. 


\section{Background}

In health accreditation a standard is "a desired and achievable level of performance against which actual performance is measured" [1]. Standards enable "health service organisations, large and small, to embed practical and effective quality improvement and patient safety initiatives into their daily operations" [2]. External organisational and clinical accreditation standards are considered necessary to promote high quality, reliable and safe products and services $[2,3]$. There are over 70 national healthcare accreditation agencies worldwide that develop or apply standards, or both, specifically for health services and organisations [4].

The International Society for Quality in Health Care (ISQua) seeks to guide and standardise the development of these agencies and the standards they implement [5]. ISQua advocates that accreditation standards themselves need to meet exacting standards, and has standards for how to develop, write and apply them. ISQua conducts the International Accreditation Program (IAP) for the certification or accreditation of standards against their standards [5]. The International Standards Organisation (ISO), a network of the national standards institutes of 162 countries, is the largest developer and publisher of international standards [6]. Standards from ISO are also applied in international health jurisdictions.

In short, healthcare standards, and standards for standards, are ubiquitous. They are advocated to be an important means of improving clinical practice and organisational performance. ISQua, and many national bodies, espouse, and have documented methodologies to promote open, transparent, inclusive development processes where standards are developed by members [6-11]. They assert that their methodologies are effective and efficient at producing standards appropriate for the health industry. However, the evidence to support these claims requires scrutiny. What is the basis to ground the standard development methodologies in use? What research demonstrates how standards should be crafted and structured to ensure they are understandable, unambiguous, achievable and reliable in making assessments? What studies have identified the necessary steps to enable standards to be incorporated into everyday practice? Is there evidence to show whether standards improve practice? The purpose of this study was to examine these questions by identifying and analysing the research literature focusing on the development methods and application of healthcare accreditation standards.

The analysis is a systematic narrative synthesis of the literature [12]. The intention is to generate new insights and bring transparency to the topic under investigation $[13,14]$. This type of review is appropriate for this topic for four reasons. First, the review aims to examine a complex initiative applied in diverse contexts [15]. That is, accreditation programs are complex organisational interventions, trying to shape both organisational and clinical conduct, within a multifaceted context in turn shaped by, for example, the healthcare and policy environment. Second, accreditation programs, involving healthcare standards, have been researched in different ways by divergent groups. The analysis method adopted here is intended specifically for interventions researched in a myriad of ways [12]. Third, the approach enables consideration of apparently disparate data generated by research into accreditation standards, as a complex organisational intervention [15]. Fourth, the questions being investigated are preliminary questions that need to be asked of this intervention and the approach is designed exactly for this $[14,15]$. The review differs from previous reviews $[16,17]$ in being specifically focused only on healthcare accreditation standards and not the broader "standards" field. This review is the first to undertake a systematic and detailed narrative synthesis of accreditation standards.

\section{Methods}

\section{Selection criteria and search strategy}

The selection criteria were: peer-reviewed, publicly available English language empirical research papers on the topic of healthcare accreditation standards. Discussion and commentary, and non-English language papers were excluded. Despite these focused criteria, we recognise that they may capture heterogeneous literature including, possibly, an overlap with work covering other forms of regulation. To counter this potential problem we used a staged search strategy to identify and remove any papers not focused on the study topic. This approach is valid for two reasons. First, there are overlaps between how regulatory strategies are at times discussed in the literature [18-20]. The reviewing of abstracts or the full papers provided a mechanism by which to screen out literature not on the study topic. Second, previous reviews and a preliminary investigation signalled that empirical research literature available on standards was limited.

A multi-method strategy based on similar review designs was employed $[16,21,22]$. There were three stages (see Figure 1). The search was first conducted in March 2010 and updated in August 2011. Citations and abstracts that met the search criteria were downloaded into Endnote X.0.2, a reference management program. Abstracts and, where uncertainty arose, complete papers, were reviewed against the selection criteria for inclusion in the review.

The first stage had three steps. First, we selected databases in the health sector. Literature was drawn from five electronic bibliographic databases: Medline, Psych INFO, EMBASE and Social Work databases from 1980, and CINAHL (nursing and allied health literature) from 1982. Second, we identified abstracts focusing on the topic of 'accreditation'. Third, we selected abstracts using the terms 'standard,' 'guideline,' 'policy' and 'legislation'; where appropriate, terms were truncated with the symbol '\$” and 


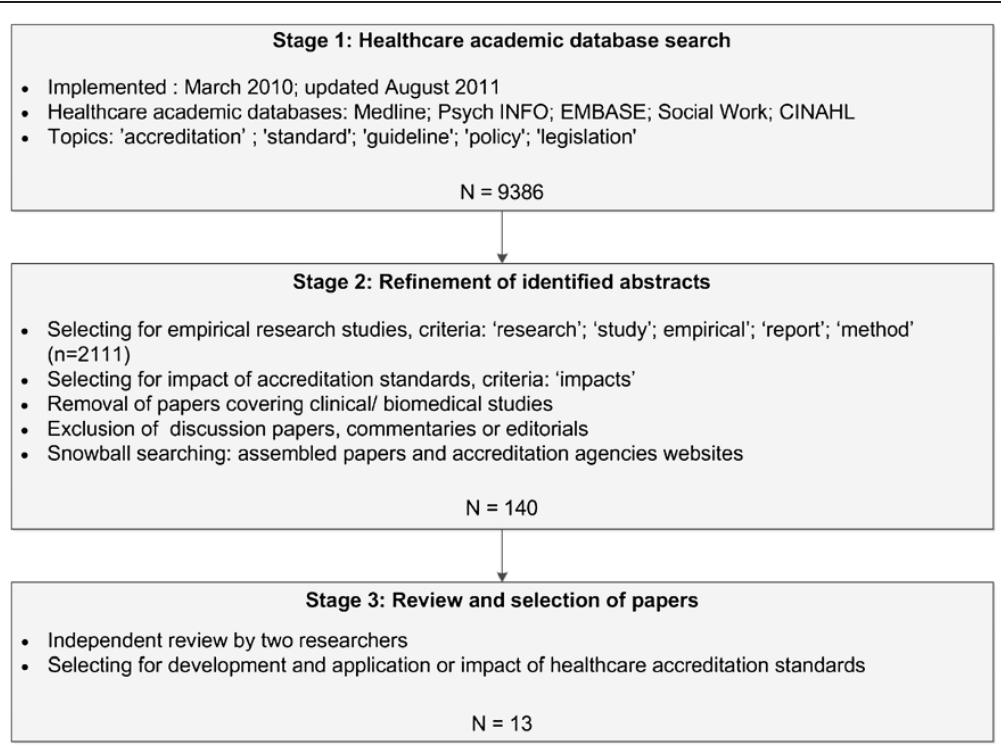

Figure 1 Literature search, review and selection flow chart.

searched using the 'Exp' function to capture widest publication of papers (for example, guideline\$ or polic\$). The initial search yielded 9386 abstracts (including duplicates). We reviewed the selection to exclude those not written in English and also to remove duplicates.

In the second stage we refined the collected abstracts. Two researchers independently reviewed the abstracts, selecting papers using two criteria. We selected for empirical research studies, using derivations of phrases such as 'research', 'study', 'empirical' or 'report', and 'method'. Using this strategy the selection was reduced to 2111 articles. This group was further analysed to identify those papers that covered 'impacts' of accreditation standards. At this point we removed papers covering clinical or biomedical issues and also discussion pieces, commentaries or editorials. To supplement the formal search process, two less structured search methods were implemented. We undertook a 'snowballing' search, which is a variation on snowballing sampling [23]. That is, we examined the assembled manuscripts reference lists for additional relevant papers potentially missed in the formal search. In parallel, an investigation of websites of agencies associated with the study topic, that is, reports or papers investigating the evidence base for accreditation or quality standards in the health sector, was conducted. We searched: the ISQua research site; the websites of 31 healthcare accreditation agencies worldwide; ISO website; and standards organisations' websites of a number of countries (Additional file 1: Appendix 1). The application of the stage 2 refinement processes to the collected abstracts yielded 140 articles.

In the third stage, to determine the final selection of papers meeting the study criteria, two experienced researchers independently reviewed the identified 140 papers and discussed their relevance. The focus was the selection of papers that addressed development methods and application of healthcare accreditation standards. This stage derived 13 articles.

\section{Analysis}

The selected papers were analysed by three independent researchers in two ways. First, the characteristics of the studies were noted. For each paper a summary of authors, country, sector, aim, methods, major findings and conclusions, and study quality was compiled. The level of evidence was assessed using Australian National Health and Medical Research Council guidelines [24] and study quality by an assessment tool developed from publically available checklists [21,25]. Together they enabled examination of study quality, incorporating intervention or aetiology (that is, impact), level of evidence, design and appraisal of quality (Table 1). Second, a narrative analysis of the literature was conducted in line with the study aims.

\section{Results}

The 13 papers were synthesised (Table 2). The results are presented under three headings: standards development; implementation issues; and the impact of standards. The papers were examined according to date of publication, country, sector, methodology and focus.

\section{Study details, characteristics and quality}

The dates of the studies ranged from 1995 to 2009 inclusive. The majority of studies were published in two years, 2003 [20,26-29] and 2009 [17,18,30,31], with five and four 
Table 1 Quality rating assessment criteria*

\begin{tabular}{|c|c|}
\hline $\begin{array}{l}\text { For all study } \\
\text { designs }\end{array}$ & Assessment criteria \\
\hline & Clearly specified and appropriate research question \\
\hline & Clear details and justification of study design, including selection of cases and controls \\
\hline & Detailed description of research setting, data collection methods and type of analysis performed \\
\hline & Logical presentation and discussion of results and study conclusions \\
\hline & Adequate sample size and response rate $(>60 \%)$ relative to study design \\
\hline Overall ratings & Assessment criteria \\
\hline+++ & All of the above criteria fulfilled \\
\hline++ & $\begin{array}{l}\text { Almost all of the above criteria fulfilled, and those criteria that were not fulfilled were thought unlikely to alter the conclusions } \\
\text { of the study }\end{array}$ \\
\hline+ & $\begin{array}{l}\text { Some of the criteria were fulfilled, and those criteria that were not fulfilled were thought unlikely to alter the conclusions of } \\
\text { the study }\end{array}$ \\
\hline
\end{tabular}

*adapted from Cunningham et al. 2011.

studies, respectively. One study was published in each of the following years: 1995 [32], 2004 [33], 2007 [34] and 2008 [35]. Studies were conducted in six countries. The United States of America (USA) was the setting for the majority of studies $(n=8)[17,18,26,29,31-34]$. The remaining five countries all had one study: United Kingdom [35]; Philippines [30]; Australia [20]; South Africa [27]; and Taiwan [28]. The studies were all conducted in the acute sector $(n=13)$. The majority of studies had a multidisciplinary focus $(n=9)[17,18,20,26-28,32-34]$ and the practices of nurses [30,35] and managers $[29,31]$ were the individual focus of two studies each. Research projects used mixed methods [20,32-35], employed quantitative methodologies to examine archival databases $[17,18,26,28,31]$ or undertook a questionnaire survey $[27,29,30]$. Within the mixed methods studies the qualitative tools were questionnaires, surveys, interviews, reviews and evaluations. The quantitative methods covered examination of databases, prospective and retrospective studies and stratified randomised studies. The study content was categorised according to the focus of the papers, that is, program, clinical or workplace issues. Program issues was the topic that most studies examined via four different program sub-topics: reviews of programs $(n=5)[18,20,28,29,31]$; policy compliance $(n=4)$ $[17,32-34]$; program impacts $(n=3)[26,27,30]$; and organisational environment $(n=1)$ [35]. Just five studies had content relating to clinical care $[17,18,20,26,34]$ and one on staff workplace issues [35].

A summary of the intervention or impact (aetiology) assessment, level of evidence classification and quality ratings for the selected literature is represented in Table 3. Using the NHMRC guidelines, three investigations [27,32,35] were classified as interventions and ten studies [20,26, 28-33,36] under the aetiology criteria. In the intervention group, Aiken et al. (2008), was assessed as meeting the fourth level of evidence and all the quality criteria. While Salmon et al. (2003) and Stradling et al. (2007) were rated at the second and fourth level of evidence rating, respectively, each were missing some study details and so were rated at the second level for quality ratings. The studies within the aetiology group were divided between the two top quality levels. Six $[26,29,30,32,33,36]$ were rated as meeting all criteria, and four [28,29,31,37], while missing some but not significant information to compromise them, were rated on the second tier of quality.

\section{Standards development}

No study directly examined standards development or other issues associated with their progression. That is, no empirical study was identified which examined: what is best practice for developing standards; standard development processes; the wording or structure of standards; or what types of standards would have the greatest likelihood of improving practice.

\section{Implementation issues}

Only one study examined implementation issues with healthcare accreditation standards [33]. Five factors were noted as assisting implementation: external pressure from legislation and accreditation; the use of technology and self-evaluation as tools to leverage change; organisational culture characteristics; research; and peer education. Conversely, three factors were reported to hinder implementation: lack of external incentives or pressure; organisational policies and culture; and cost and resource constraints [33].

\section{Impact of standards}

Twelve of the 13 papers addressed the impact of standards [26-32,35-37]. The impact of the standards on the organisation, clinical quality and staff could be identified. 
Table 2 Assessment of empirical healthcare standards research

\begin{tabular}{|c|c|c|c|c|c|c|c|c|c|}
\hline \multicolumn{3}{|c|}{ Study details } & \multicolumn{3}{|c|}{ Study characteristics } & \multicolumn{4}{|c|}{ Study quality } \\
\hline Author-year & Country & Sector & Aim & Methods & $\begin{array}{l}\text { Major findings } \\
\text { and conclusions }\end{array}$ & $\begin{array}{c}\text { Intervention } \\
\text { or Aetiology } \\
\text { (I or A) } \\
\text { (NHMRC } \\
\text { hierarchy) }\end{array}$ & $\begin{array}{l}\text { Level of } \\
\text { evidence } \\
\text { (NHMRC } \\
\text { hierarchy) }\end{array}$ & Design & $\begin{array}{c}\text { Quality } \\
\text { rating }\end{array}$ \\
\hline $\begin{array}{l}\text { Aiken et al. } \\
\text { (2008) [35] }\end{array}$ & $\begin{array}{l}\text { United } \\
\text { Kingdom }\end{array}$ & $\begin{array}{l}\text { Acute } \\
\text { care }\end{array}$ & $\begin{array}{l}\text { To test the } \\
\text { impact of the } \\
\text { implementation } \\
\text { of Magnet } \\
\text { principles of } \\
\text { improving } \\
\text { nurses' work } \\
\text { environments. }\end{array}$ & $\begin{array}{l}\text { Survey } \\
\text { Comparison } \\
\text { with national } \\
\text { sample }\end{array}$ & $\begin{array}{l}\text { Pre-survey: nurse } \\
\text { work environment } \\
\text { was less positive } \\
\text { and they } \\
\text { experienced less } \\
\text { job satisfaction } \\
\text { than the national } \\
\text { sample. } \\
\text { Post-survey: } \\
\text { significant } \\
\text { improvement in } \\
\text { nurse practice } \\
\text { environment, job } \\
\text { satisfaction and } \\
\text { appraisals of the } \\
\text { quality of patient } \\
\text { care; practice } \\
\text { environment better } \\
\text { than national } \\
\text { sample. The } \\
\text { implementation of } \\
\text { the Magnet } \\
\text { hospital program } \\
\text { was associated } \\
\text { with a significantly } \\
\text { improved nursing } \\
\text { work environment } \\
\text { as well as } \\
\text { improved job- } \\
\text { related outcomes } \\
\text { for nurses and } \\
\text { markers for quality } \\
\text { of patient care. }\end{array}$ & I & IV & $\begin{array}{l}\text { Pre- and } \\
\text { post- evaluation } \\
\text { Compar-ative } \\
\text { study }\end{array}$ & +++ \\
\hline $\begin{array}{l}\text { Devers, } \\
\text { Pham, Liu } \\
\text { (2004) [34] }\end{array}$ & $\begin{array}{l}\text { United } \\
\text { States }\end{array}$ & $\begin{array}{l}\text { Acute } \\
\text { care }\end{array}$ & $\begin{array}{l}\text { To describe } \\
\text { hospitals' } \\
\text { patient-safety } \\
\text { initiatives, and } \\
\text { the relative roles } \\
\text { that regulation, } \\
\text { markets and } \\
\text { professionalism } \\
\text { have in } \\
\text { stimulating } \\
\text { progress. }\end{array}$ & $\begin{array}{l}\text { Interviews } \\
\text { with } \\
\text { stakeholders } \\
\\
\text { Database } \\
\text { analysis (CTS } \\
\text { patient safety } \\
\text { and Leapfrog } \\
\text { Group survey } \\
\text { data) }\end{array}$ & $\begin{array}{l}\text { Hospitals' major } \\
\text { patient-safety } \\
\text { initiatives were } \\
\text { primarily intended } \\
\text { to meet Joint } \\
\text { Commission (JC) } \\
\text { requirements. } \\
\text { Internal } \\
\text { (professionalism, } \\
\text { resources), external } \\
\text { (regulation, } \\
\text { markets) and } \\
\text { contextual } \\
\text { (research, } \\
\text { organisational } \\
\text { factors) facilitators } \\
\text { and barriers } \\
\text { identified. } \\
\text { Impact on } \\
\text { hospitals of } \\
\text { increased attention } \\
\text { to patient safety } \\
\text { has been mixed } \\
\text { and on patients it } \\
\text { is unclear, because } \\
\text { relevant data did } \\
\text { not exist or were } \\
\text { difficult to } \\
\text { interpret. }\end{array}$ & A & IV & Cross sectional & +++ \\
\hline
\end{tabular}


Table 2 Assessment of empirical healthcare standards research (Continued)

\begin{tabular}{|c|c|c|c|c|c|c|c|c|c|}
\hline & & & & & $\begin{array}{l}\text { Professional and } \\
\text { market initiatives } \\
\text { have facilitated } \\
\text { improvement, } \\
\text { however quasi- } \\
\text { regulatory forces, } \\
\text { such as JC, are } \\
\text { having the greatest } \\
\text { impact on } \\
\text { hospitals' patient- } \\
\text { safety efforts. }\end{array}$ & & & & \\
\hline $\begin{array}{l}\text { Herr, Titler } \\
\text { (2009) [17] }\end{array}$ & $\begin{array}{l}\text { United } \\
\text { States }\end{array}$ & $\begin{array}{l}\text { Acute } \\
\text { care }\end{array}$ & $\begin{array}{l}\text { To examine } \\
\text { compliance with } \\
\text { the new pain } \\
\text { assessment and } \\
\text { management } \\
\text { standards of } \\
\text { the Joint } \\
\text { Commission on } \\
\text { Accreditation of } \\
\text { Healthcare } \\
\text { Organizations } \\
\text { (JCAHO) for } \\
\text { accredited } \\
\text { health care } \\
\text { organisations. }\end{array}$ & $\begin{array}{l}\text { Archival } \\
\text { documents } \\
\text { analysis }\end{array}$ & $\begin{array}{l}\text { Trends over time } \\
\text { illustrate } \\
\text { improvements in } \\
\text { pain assessment } \\
\text { practices, with a } \\
\text { majority of patients } \\
\text { having some } \\
\text { documentation } \\
\text { related to pain. } \\
\text { However, only just } \\
\text { over half the } \\
\text { patients had } \\
\text { medicines ordered. } \\
\text { Practice } \\
\text { improvement in } \\
\text { the administration } \\
\text { of medicine was } \\
\text { noted. } \\
\text { Pain assessment } \\
\text { and management } \\
\text { practices in the } \\
\text { emergency } \\
\text { departments } \\
\text { showed } \\
\text { improvements in } \\
\text { line with the } \\
\text { introduction of } \\
\text { standards. }\end{array}$ & $A$ & || $\mid-2$ & $\begin{array}{l}\text { Retrospective } \\
\text { cross sectional, } \\
\text { cohort study }\end{array}$ & +++ \\
\hline $\begin{array}{l}\text { Kozhimannil } \\
\text { et al. (2009) } \\
\text { [30] }\end{array}$ & Philippines & $\begin{array}{l}\text { Acute } \\
\text { care }\end{array}$ & $\begin{array}{l}\text { To examine the } \\
\text { population-level } \\
\text { impacts of two } \\
\text { programs - } \\
\text { national health } \\
\text { insurance } \\
\text { (PhilHealth) and } \\
\text { a donor funded } \\
\text { franchise of } \\
\text { midwife clinics } \\
\text { (Well Family } \\
\text { Midwife Clinics) } \\
\text { on achievement } \\
\text { of minimum } \\
\text { standards for } \\
\text { prenatal and } \\
\text { delivery care. }\end{array}$ & Survey & $\begin{array}{l}\text { The PhilHealth } \\
\text { insurance program } \\
\text { scale was } \\
\text { associated with } \\
\text { increased odds of } \\
\text { receiving at least } \\
\text { four prenatal visits } \\
\text { and receiving a } \\
\text { visit during the first } \\
\text { trimester of } \\
\text { pregnancy. } \\
\text { Exposure to } \\
\text { midwife clinics was } \\
\text { not associated with } \\
\text { significant changes } \\
\text { in achievement of } \\
\text { prenatal care } \\
\text { standards. The } \\
\text { expansion of an } \\
\text { insurance program } \\
\text { with accreditation } \\
\text { standards was } \\
\text { associated with } \\
\text { increases in } \\
\text { achievement of } \\
\text { minimal standards } \\
\text { of prenatal care } \\
\text { among women. }\end{array}$ & A & || $\mid-2$ & $\begin{array}{l}\text { Pre- and post- } \\
\text { evaluation, } \\
\text { longitudinal study }\end{array}$ & +++ \\
\hline
\end{tabular}


Table 2 Assessment of empirical healthcare standards research (Continued)

\begin{tabular}{|c|c|c|c|c|c|c|c|c|c|}
\hline $\begin{array}{l}\text { Lamb et al. } \\
\text { (2003) [29] }\end{array}$ & $\begin{array}{l}\text { United } \\
\text { States }\end{array}$ & $\begin{array}{l}\text { Acute } \\
\text { care }\end{array}$ & $\begin{array}{l}\text { To investigate } \\
\text { how hospitals } \\
\text { are dealing with } \\
\text { the JCAHO } \\
\text { standard that } \\
\text { requires that all } \\
\text { unanticipated } \\
\text { outcomes of } \\
\text { care are } \\
\text { disclosed. }\end{array}$ & $\begin{array}{l}\text { Survey } \\
\text { (Completion } \\
\text { rate 51\%) }\end{array}$ & $\begin{array}{l}\text { The vast majority } \\
\text { of risk managers } \\
\text { reported that their } \\
\text { hospital's practice } \\
\text { was to disclose } \\
\text { harm at least some } \\
\text { of the time, } \\
\text { although only one } \\
\text { third of hospitals } \\
\text { actually have } \\
\text { board-approved } \\
\text { policies in place. } \\
\text { More than half of } \\
\text { respondents } \\
\text { reported they } \\
\text { would always } \\
\text { disclose death or } \\
\text { serious injury, but } \\
\text { when presented } \\
\text { with actual clinical } \\
\text { scenarios, } \\
\text { respondents were } \\
\text { much less likely to } \\
\text { disclose } \\
\text { preventable harms } \\
\text { than to disclose } \\
\text { non-preventable } \\
\text { harms of } \\
\text { comparable } \\
\text { severity. Reluctance } \\
\text { to disclose } \\
\text { preventable harms } \\
\text { was twice as likely } \\
\text { to occur at } \\
\text { hospitals having } \\
\text { major concerns } \\
\text { about malpractice } \\
\text { implications of } \\
\text { disclosure. }\end{array}$ & $A$ & IV & $\begin{array}{l}\text { Stratified random } \\
\text { sample of } \\
\text { hospitals }\end{array}$ & ++ \\
\hline $\begin{array}{l}\text { Longo et al. } \\
\text { (1995) [32] }\end{array}$ & $\begin{array}{l}\text { United } \\
\text { States }\end{array}$ & $\begin{array}{l}\text { Acute } \\
\text { care }\end{array}$ & $\begin{array}{l}\text { To examine } \\
\text { compliance and } \\
\text { characteristics of } \\
\text { hospitals with } \\
\text { tobacco control } \\
\text { standards } \\
\text { enacted by } \\
\text { the Joint } \\
\text { Commission on } \\
\text { Accreditation of } \\
\text { Healthcare } \\
\text { Organisations. } \\
\text { (JCAHO) }\end{array}$ & $\begin{array}{l}\text { Onsite } \\
\text { assessment of } \\
\text { hospitals } \\
\text { during period } \\
\text { 1992-3 } \\
\text { (N=3327) } \\
\text { Archival data }\end{array}$ & $\begin{array}{l}\text { Two years after } \\
\text { implementation, } \\
95.6 \% \text { of hospitals } \\
\text { met the new } \\
\text { JCAHO smoking } \\
\text { ban standard; } \\
90.9 \% \text { of hospitals } \\
\text { were in } \\
\text { compliance with a } \\
\text { second smoking } \\
\text { standard requiring } \\
\text { development and } \\
\text { use of medical } \\
\text { criteria for } \\
\text { physician-ordered } \\
\text { exceptions to the } \\
\text { ban. Hospitals in } \\
\text { tobacco-producing } \\
\text { states had higher- } \\
\text { than-average rates } \\
\text { of compliance } \\
\text { when compared to } \\
\text { hospitals in other } \\
\text { states. Hospitals } \\
\text { providing } \\
\text { psychiatric and/or } \\
\text { substance abuse } \\
\text { services had lower- } \\
\text { than-average rates } \\
\text { of compliance. }\end{array}$ & A & IV & Cross sectional & +++ \\
\hline
\end{tabular}


Table 2 Assessment of empirical healthcare standards research (Continued)

\begin{tabular}{|c|c|c|c|c|c|c|c|c|c|}
\hline & & & & & $\begin{array}{l}\text { This first industry- } \\
\text { wide smoking ban } \\
\text { has been } \\
\text { successful. } \\
\text { However, hospitals } \\
\text { should consider } \\
\text { evaluating the use } \\
\text { of medical } \\
\text { exceptions to this } \\
\text { policy. }\end{array}$ & & & & \\
\hline $\begin{array}{l}\text { Piontek et al. } \\
\text { (2003) [26] }\end{array}$ & $\begin{array}{l}\text { United } \\
\text { States }\end{array}$ & $\begin{array}{l}\text { Acute } \\
\text { care }\end{array}$ & $\begin{array}{l}\text { To compare the } \\
\text { impact of } \\
\text { trauma patient } \\
\text { outcomes } \\
\text { before and after } \\
\text { Level II } \\
\text { American } \\
\text { College of } \\
\text { Surgeons (ACS) } \\
\text { verification was } \\
\text { received in a } \\
\text { not-for-profit } \\
\text { community } \\
\text { hospital. }\end{array}$ & $\begin{array}{l}\text { Database } \\
\text { analysis }\end{array}$ & $\begin{array}{l}\text { Study variable } \\
\text { exhibited } \\
\text { statistically } \\
\text { different outcomes: } \\
\text { length of stay } \\
\text { (LOS) } 10 \% \text { less } \\
(p<0.000) ; \text { ratio of } \\
\text { costs was } 5 \% \text { lower } \\
\text { ( } p<0.000) \text {; and } \\
\text { mortality observed } \\
\text { /expected ratios } \\
\text { significantly } \\
\text { different (0.81 } \\
\text { before versus } 0.59 \\
\text { after [p }<0.000]) \text {. } \\
\text { The resources } \\
\text { consumed } \\
\text { achieving ACS } \\
\text { Level II trauma } \\
\text { centre verification } \\
\text { resulted in } \\
\text { decreased LOS, } \\
\text { reduced in-hospital } \\
\text { mortality rates, } \\
\text { reduced cost and } \\
\text { improved } \\
\text { contribution } \\
\text { margins. }\end{array}$ & $A$ & $111-3$ & Case control & ++ \\
\hline $\begin{array}{l}\text { Rowe- } \\
\text { Murray } \\
\text { and Fisher } \\
\text { (2003) [20] }\end{array}$ & Australia & $\begin{array}{l}\text { Acute } \\
\text { care }\end{array}$ & $\begin{array}{l}\text { To test the } \\
\text { hypothesis that } \\
\text { hospital } \\
\text { practices in the } \\
\text { immediate post } \\
\text { partum period } \\
\text { that are } \\
\text { associated with } \\
\text { operative } \\
\text { intervention in } \\
\text { delivery can } \\
\text { affect the } \\
\text { implementation } \\
\text { of the Baby } \\
\text { Friendly Hospital } \\
\text { Initiative Step } \\
\text { Four. }\end{array}$ & $\begin{array}{l}\text { Prospective } \\
\text { longitudinal } \\
\text { study } \\
\text { Interview } \\
\text { ( } n=203) \\
\text { Document } \\
\text { analysis } \\
\text { Survey }\end{array}$ & $\begin{array}{l}\text { Women who had a } \\
\text { caesarean section } \\
\text { experienced } \\
\text { significant delay in } \\
\text { initiating } \\
\text { breastfeeding } \\
\text { compared with } \\
\text { women giving } \\
\text { birth vaginally with } \\
\text { or without } \\
\text { instrumental } \\
\text { assistance } \\
\text { ( } p<0.001) \text {. } \\
\text { Significant } \\
\text { differences were } \\
\text { observed among } \\
\text { hospitals with Baby } \\
\text { Friendly } \\
\text { performing } \\
\text { significantly better } \\
\text { than the other } 3 \\
\text { hospitals } \\
\text { ( } p<0.001 \text { ). } \\
\text { Birth delivery } \\
\text { affected the } \\
\text { implementation of } \\
\text { Baby Friendly } \\
\text { Hospital Initiative } \\
\text { Step Four. }\end{array}$ & A & $\|$ & Prospective cohort & ++ \\
\hline
\end{tabular}


Table 2 Assessment of empirical healthcare standards research (Continued)

\begin{tabular}{|c|c|c|c|c|c|c|c|c|c|}
\hline $\begin{array}{l}\text { Salmon et al. } \\
\text { (2003) [27] }\end{array}$ & $\begin{array}{l}\text { South } \\
\text { Africa }\end{array}$ & $\begin{array}{l}\text { Acute } \\
\text { care }\end{array}$ & $\begin{array}{l}\text { To test the } \\
\text { impact of } \\
\text { accreditation. }\end{array}$ & $\begin{array}{l}\text { Survey } \\
\text { (hospital } \\
\text { organisational } \\
\text { process } \\
\text { indicator data) }\end{array}$ & $\begin{array}{l}\text { Two years after the } \\
\text { introduction of } \\
\text { accreditation, the } \\
\text { intervention group } \\
\text { compliance with } \\
\text { standards } \\
\text { increased (38\% to } \\
76 \% \text { ) and the } \\
\text { control group } \\
\text { maintained level } \\
(37 \% \text { top 38\%). The } \\
\text { accreditation } \\
\text { program facilitated } \\
\text { public hospitals' } \\
\text { compliance with } \\
\text { standards. }\end{array}$ & I & $\|$ & $\begin{array}{l}\text { Randomised } \\
\text { control trial }\end{array}$ & ++ \\
\hline $\begin{array}{l}\text { Stradling et } \\
\text { al. (2007) } \\
{[34]}\end{array}$ & $\begin{array}{l}\text { United } \\
\text { States }\end{array}$ & $\begin{array}{l}\text { Acute } \\
\text { care }\end{array}$ & $\begin{array}{l}\text { To examine } \\
\text { stroke care } \\
\text { delivery before } \\
\text { and after Joint } \\
\text { Commission } \\
\text { stroke center } \\
\text { certification. }\end{array}$ & $\begin{array}{l}\text { Document } \\
\text { analysis } \\
\text { Database } \\
\text { analysis }\end{array}$ & $\begin{array}{l}\text { Certification } \\
\text { improved clinical } \\
\text { care (testing and } \\
\text { medication) for } \\
\text { patients with } \\
\text { ischemic stroke. } \\
\text { Clinical care } \\
\text { improved with the } \\
\text { certification of } \\
\text { stroke centres. }\end{array}$ & $A$ & IV & $\begin{array}{l}\text { Pre- and post- } \\
\text { evaluation }\end{array}$ & ++ \\
\hline $\begin{array}{l}\text { Thornlow } \\
\text { and Merwin } \\
\text { (2009) [18] }\end{array}$ & $\begin{array}{l}\text { United } \\
\text { States }\end{array}$ & $\begin{array}{l}\text { Acute } \\
\text { care }\end{array}$ & $\begin{array}{l}\text { To examine the } \\
\text { relationship } \\
\text { between patient } \\
\text { safety practices, } \\
\text { as measured by } \\
\text { accreditation } \\
\text { standards, and } \\
\text { patient safety } \\
\text { outcomes as } \\
\text { measured by } \\
\text { hospital rates of } \\
\text { infections, } \\
\text { decubitus ulcers, } \\
\text { postoperative } \\
\text { respiratory } \\
\text { failure, and } \\
\text { failure to rescue. }\end{array}$ & $\begin{array}{l}\text { Database } \\
\text { analysis } \\
\text { (secondary } \\
\text { data) }\end{array}$ & $\begin{array}{l}\text { Accreditation } \\
\text { standards reflecting } \\
\text { patient safety } \\
\text { practices were } \\
\text { related to some } \\
\text { outcomes, but not } \\
\text { others. Rates of } \\
\text { infections and } \\
\text { decubitus ulcers } \\
\text { occurred more } \\
\text { frequently in } \\
\text { hospitals with } \\
\text { poorer } \\
\text { performance in } \\
\text { utilizing patient } \\
\text { safety practices, } \\
\text { but no differences } \\
\text { were noted in rates } \\
\text { of postoperative } \\
\text { respiratory failure } \\
\text { or failure to rescue. } \\
\text { Certain adverse } \\
\text { events, such as } \\
\text { infections and } \\
\text { decubiti, may be } \\
\text { reduced by } \\
\text { preventive } \\
\text { protocols that are } \\
\text { reflected in } \\
\text { accreditation } \\
\text { standards, whereas } \\
\text { other events, such } \\
\text { as failure to } \\
\text { rescues and } \\
\text { postoperative } \\
\text { respiratory failure, } \\
\text { may require } \\
\text { multifaceted } \\
\text { strategies that are } \\
\text { less easily }\end{array}$ & A & IV & Cross-sectional & +++ \\
\hline
\end{tabular}


Table 2 Assessment of empirical healthcare standards research (Continued)

\begin{tabular}{|c|c|c|c|c|c|c|c|c|c|}
\hline & & & & & $\begin{array}{l}\text { translated unto } \\
\text { protocols. }\end{array}$ & & & & \\
\hline $\begin{array}{l}\text { Valenstein et } \\
\text { al. (2009) } \\
{[31]}\end{array}$ & $\begin{array}{l}\text { United } \\
\text { States }\end{array}$ & $\begin{array}{l}\text { Acute } \\
\text { care }\end{array}$ & $\begin{array}{l}\text { To determine } \\
\text { how document } \\
\text { control is being } \\
\text { implemented in } \\
\text { practice and } \\
\text { whether } \\
\text { particular } \\
\text { approaches } \\
\text { result in better } \\
\text { levels of } \\
\text { compliance. }\end{array}$ & $\begin{array}{l}\text { Document } \\
\text { analysis }\end{array}$ & $\begin{array}{l}35 \% \text { fulfilled all } 6 \\
\text { document control } \\
\text { requirements } \\
(3113 / 8814) ; 97 \% \\
\text { met the } \\
\text { requirements for } \\
\text { the availability of } \\
\text { the document; } \\
50 \% \text { fulfilled } \\
\text { archiving } \\
\text { requirements. } \\
\text { Policies and } \\
\text { procedures were } \\
\text { more likely to fulfil } \\
\text { document control } \\
\text { requirements than } \\
\text { forms and work } \\
\text { aids. Document } \\
\text { control practices } \\
\text { significantly } \\
\text { associated with } \\
\text { higher compliance } \\
\text { rates were unable } \\
\text { to be identified. } \\
\text { Most laboratories } \\
\text { are not meeting } \\
\text { regulatory and } \\
\text { accreditation } \\
\text { requirements } \\
\text { related to the } \\
\text { control of } \\
\text { documents. }\end{array}$ & $A$ & IV & $\begin{array}{l}\text { Prospective cross } \\
\text { sectional }\end{array}$ & ++ \\
\hline $\begin{array}{l}\text { Weng et al. } \\
\text { (2003) [28] }\end{array}$ & Taiwan & $\begin{array}{l}\text { Acute } \\
\text { care }\end{array}$ & $\begin{array}{l}\text { To examine the } \\
\text { effect of the } \\
\text { Baby Friendly } \\
\text { Hospital } \\
\text { Initiative (BFHI) } \\
\text { on the } \\
\text { Taiwanese } \\
\text { breastfeeding } \\
\text { rate and analyse } \\
\text { factors related } \\
\text { to BFHI } \\
\text { qualification. }\end{array}$ & $\begin{array}{l}\text { Document } \\
\text { analysis }\end{array}$ & $\begin{array}{l}\text { Mothers in } \\
\text { qualified BFHI } \\
\text { had higher } \\
\text { breastfeeding rates } \\
\text { than those in non- } \\
\text { qualified hospitals } \\
\text { whether they were } \\
\text { surveyed while in } \\
\text { maternity wards } \\
\text { after delivery } \\
\text { (88.1\% vs } 78.1 \% \text { ) or } \\
\text { in their first post- } \\
\text { natal month (67.6\% } \\
\text { vs } 59.4 \% \text { ). Close } \\
\text { correlation } \\
\text { between BFHI } \\
\text { qualification and } \\
\text { location and grade } \\
\text { of hospital. Factors } \\
\text { related to } \\
\text { qualification were: } \\
\text { hospital fosters } \\
\text { establishment of } \\
\text { breastfeeding } \\
\text { support groups; } \\
\text { written } \\
\text { breastfeeding } \\
\text { policy; practise } \\
\text { rooming-in } \\
\text { available } 24 \text { hours } \\
\text { a day; and health } \\
\text { staff trained. Health }\end{array}$ & $A$ & IV & $\begin{array}{l}\text { Retrospective } \\
\text { cross sectional }\end{array}$ & ++ \\
\hline
\end{tabular}




\section{Impacts of standards on the organisation}

The single randomised controlled trial identified demonstrated that compliance with accreditation standards increased in the intervention group, from 38 to $76 \%$, compared to in the control group, from 37 to $38 \%$ [27]. Furthermore, standards or guidelines about the organisation of clinical practice led to improved efficiency and quality practices. Specifically, standards within an accreditation program resulted in decreased length of hospital stay [26], improved management of disclosure of preventable harm [29], and utilisation of patient safety practices [36].

\section{Impacts of standards on clinical quality}

Accreditation program standards encompassing trauma care [26], prenatal care [30], post partum care [37], stroke care [32], breastfeeding [28], pain management [29], and the institution wide organisation of care [27,30,33] were reported to improve the provision of care. Additionally, there were links to improvements in various aspects of clinical quality. For example, standards contributed to: reductions in in-hospital mortality and length of stay [26], and rates of infections and decubitus ulcers [36]; and improvements in breastfeeding rates [28] and the proportion of patients receiving relevant tests, medications and admission for stroke [32]. Conversely, and at times simultaneously, standards introduced to improve care appeared not to do so. For example, exposure to standards for prenatal and delivery care [30], document control [31], and the organisation of care [27] did not show any measurable effects. Nor did rates of certain adverse events, such as failure to rescue or postoperative respiratory failure, alter with the implementation of accreditation standards [36].

\section{Impact on staff}

Standards were shown to produce an improved staff quality of life, working conditions and appraisals of the quality of care. This outcome was noted from the use of 'Magnet' principles, which sought to improve the attraction of the workplace in recruiting and retaining staff [35]. Additionally, the introduction of standards, through an accreditation program, resulted in the improved perceptions of teamwork and participation in decision making [27], and compliance with tobacco control [32].

\section{Discussion}

This study employed systematic search procedures to academic databases and accreditation agency websites to uncover empirical research that grounds the development methods and application of healthcare accreditation standards. The review has built on previous work in the healthcare accreditation field [16,17], commencing where previous reviews finished. We started with a proposition that standards are ubiquitous within healthcare and are generally considered to be an important means by which to improve clinical practice and organisational performance. However, the evidence about whether accreditation standards change behaviour of health care organisations, clinical quality and staff is at best equivocal, and is determined by the circumstances.

Table 3 Summary of the intervention or aetiology assessment, level of evidence classification and quality ratings

\begin{tabular}{llc}
\hline Level of evidence & Quality ratings & ++ \\
\hline II & +++ & Salmon et al. (2003) [27] \\
\hline III-2 & Rowe-Murray and Fisher (2003) [20] & Stradling et al. (2007)[34] \\
\hline III-3 & Piontek et al. (2003) [26] & Lamb et al. (2003) [29] \\
\hline AV & Aiken et al. (2008) [35] & Valenstein et al. (2009) [31] \\
\hline & Devers et al. (2004) [34] & Weng et al. (2003) [28]
\end{tabular}


Only three intervention studies were identified in the review. Two interventions resulted in improvements attributed to the implementation of accreditation standards $[32,35]$. The improvements were the organisational working environment and staff perceptions [35], and care processes and appropriateness of care [32]. The remaining study, conducted in a developing country [27], involved health services seeking improvement from a very low base and hence the applicability of the results is limited to that context. The non-intervention studies have shown that, whilst there is adherence to standards in some cases, in a range of instances there is little evidence as to their effects. In short, the effectiveness of the development, writing, implementation and impacts of healthcare standards are significant issues that lack convincing evidence.

It is not clear, for example, what might be evidencebased practice in the development of standards. However, the literature synthesis suggests that reoccurring strategies include mobilising external leverage, organising teams or creating receptive cultures within health care organisations to optimise the opportunity to create standards. Yet an overarching finding was that applying standards has mixed results. There is limited published peer-reviewed evidence regarding the correspondence between the application of standards and improvements in organisational performance, clinical quality or staff behaviours.

There is the opportunity for the standards development field to learn from the experience of people developing technical standards, practice guidelines and evidencebased clinical policies. Consideration can be given to the applicability of translation of development processes and implementation strategies from other areas in healthcare [38-40]. The Joint Commission in the USA, for example, through the establishment of the National Patient Safety Goals initiative has used development and implementation processes from which lessons can be learnt [41].

Agencies setting standards, including accreditation bodies or programs that develop or apply them, or both, also have significant experience and expertise in conducting these activities. Some have been doing so for decades. More recently, ISQua is utilising and sharing this experience through two strategies: the ISQua IAP and the accreditation workshop conducted at ISQua's annual international quality conference. The ISQua IAP has been implemented to "build credibility and comparability for national organisations by harmonising standards and procedures on common international principles" [42]:349. Established in 1999, the IAP utilises the expertise of senior people within accreditation agencies to review, offer ideas for improvements, and accredit programs in other countries. ISQua reports that the IAP has accredited 19 organisations and 35 sets of standards (from 21 organisations), and eight surveyor training programs [36]. Each year the accreditation workshop at the ISQua international quality conference draws together practitioners and researchers from around the world to consider current developments and challenges associated with healthcare accreditation programs [43]. Discussions have centred upon all aspects of accreditation programs, for example: implementation of accreditation programs $[44,45]$; maintaining standards of accreditation programs [46]; survey methodologies [47,48]; linking standards to clinical indicators [49]; processes used to develop standards [50]; and the public disclose of accreditation results [51,52].

\section{Conclusion}

The challenge is to translate practical experiences and discussions into rigorous empirical evidence. We lack knowledge of how to strengthen the development of standards and the application of them based on sound critically peerreviewed evidence. The process to develop standards essentially needs to be transformed from learnt experience to a verifiable, evidence-based methodology. Evidence-based mechanisms by which standards are developed, promulgated, reinforced, audited and evaluated are needed. Linking the writing of standards, including the wording, structure, design, focus and content, to improved outcomes requires further rigorous investigation. Factors that promote or inhibit implementation of standards, and the impacts that result, need detailed examination and analysis. This review has revealed some significant gaps in our knowledge in these areas, and, in doing so, extended previous reviews in the healthcare accreditation field.

As to the limitations of our study, while we have endeavoured to be systematic, we may have overlooked some important literature. A further limitation is that papers or reports needed to be publicly available and in English to be included in the results.

\section{Additional file}

Additional file 1: Appendix 1. Accreditation and Standards Agencies websites searched.

Competing interests

The authors declare that they have no competing interests.

\section{Authors' contributions}

DG and MP performed the literature search, and along with $\mathrm{RH}$ selected relevant papers for the review and analysed the included papers. DG, MP and $\mathrm{RH}$ drafted the initial manuscript, and all authors contributed to the revision of the manuscript. All authors read and approved the final manuscript.

\section{Acknowledgements}

We are grateful to colleagues for insightful discussions on standards and accreditation over the years including Charles Shaw, Rosa Suñol, Cathy Pope, John Øvretveit, Mark Brandon, Stephen Clarke and Brian Johnston.

\section{Funding}

This research was supported under Australian Research Council's Linkage Projects funding scheme (project number LP100200586). 
Received: 22 May 2012 Accepted: 18 September 2012

Published: 20 September 2012

\section{References}

1. International Society for Quality in Health Care: Glossary of Terms, ISQua.; 2006.

2. Accreditation Canada: Access to Standards.; 2011. http://www.accreditation. ca/Shop-for-Standards/; access date: 26/08/11.

3. Australian Commission on Safety and Quality in Health Care: National Safety and Quality Health Service Standards. Sydney, Australia: Commonwealth of Australia; 2011.

4. Academic Medical Center Working Group of the Institute for Healthcare Improvement: The imperative for quality: a call for action to medical schools and teaching hospitals. Acad Med 2003, 78(11):1085-1089.

5. Adams R, Acker J, Alberts M, Andrews L, Atkinson R, Fenelon K, Furlan A, Girgus $M$, Horton $K$, Hughes $R$, et al: Recommendations for improving the quality of care through stroke centers and systems: an examination of stroke center identification options: multidisciplinary consensus recommendations from the Advisory Working Group on Stroke Center Identification Options of the American Stroke Association. Stroke 2002, 33 (1):e1-e7.

6. International Standards Organisation: About ISO 2011.; http://www.iso.org/ iso/support/contact_iso.htm; access date: 29/07/11.

7. American National Standards Institute: About ANSI Overview:; 2011. http://www.ansi.org/; access date: 29/07/2011.

8. Standards Australia: Proposing New Projects;; 2010. http://www.standards.org.au/ DevelopingStandards/ProposingnewProjects.aspx; access date: 29/07/11.

9. Standards Council of Canada: Developing Standards 2011; http://www.scc.ca/ en/national_standards_system/developing-standards; access date: 29/07/11

10. Allsop J, Saks M: Professional regulation in primary care: the long road to quality improvement. Qual Prim Care 2008, 16(4):225-228.

11. Bristish Standards Institution: About BSI Standards.; 2011. http://www. bsigroup.com/en/Standards-and-Publications/About-BSI-British-Standards/; access date: 25/10/11.

12. Greenhalgh T, Robert G, Macfarlane F, Bate P, Kyriakidou O, Peacock R: Storylines of research in diffusion of innovation: a meta-narrative approach to systematic review. Soc Sci Med 2005, 61:417-430.

13. Pope C, Mays N, Popay J: How can we synthesize qualitative and quantitative evidence for healthcare policy-makers and managers? Healthc Manage Forum 2006, 19(1):27-31.

14. Denyer $D$, Tranfield D, van Aken JE: Developing design propositions through research synthesis. Organ Stud 2008, 29(3):393-413.

15. Greenhalgh T, Wong G, Westhorp G, Pawson R: Protocol - realist and meta-narrative evidence synthesis: evolving Standards (RAMESES). BMC Med Res Methodol 2011, 11(1):115.

16. Greenfield D, Braithwaite J: Health sector accreditation research: a systematic review. Int I Qual Health Care 2008, 20(3):172-183.

17. Herr K, Titler M: Acute pain assessment and pharmacological management practices for the older adult with a hip fracture: review of ED trends. J Emer Nurs 2009, 35(4):312-320.

18. Thornlow D, Merwin E: Managing to improve quality: the relationship between accreditation standards, safety practices, and patient outcomes. Health Care Manag Rev 2009, 34(3):262-272.

19. Lichtman JH, Allen NB, Wang Y, Watanabe E, Jones SB, Goldstein LB: Stroke patient outcomes in US hospitals before the start of the Joint Commission Primary Stroke Center certification program. Stroke 2009, 40(11):3574-3579.

20. Rowe-Murray H, Fisher J: Baby friendly hospital practices: caesarean section is a persistent barrier to early initiation of breastfeeding. Breastfeed Rev 2003, 11(1):21-27.

21. NHMRC: NHMRC levels of evidence and grades for recommendations for developers of guidelines. Canberra: National Health and Medical Research Council; 2009.

22. Mazzocato P, Savage C, Brommels M, Aronsson H, Thor J: Lean thinking in healthcare: a realist review of the literature. Qual Saf Health Care 2010, 19(5):376-382.

23. Liamputtong P: Qualitative research methods. 3rd edition. Melbourne: Oxford University Press; 2009.

24. Cunningham FC, Ranmuthugala G, Plumb J, Georgiou A, Westbrook Ji, Braithwaite J: Health professional networks as a vector for improving healthcare quality and safety: a systematic review. BMJ Qual Saf 2011, 21(3):239-249
25. Mays N, Pope C, Popay J: Systematically reviewing qualitative and quantitative evidence to inform management and policy-making in the health field. J Health Serv Res Policy 2005, 10(Suppl 1):6-20.

26. Piontek FA, Coscia R, Marselle CS, Korn RL, Zarling EJ: Impact of American College of Surgeons verification on trauma outcomes. J Trauma 2003, 54(6):1041-1046.

27. Salmon J, Heavens J, Lombard C, Tavrow P: The impact of accreditation on the quality of hospital care: KwaZulu-Natal province Republic of South Africa, Operations Research Results. Bethesda, MD: USAID; 2003.

28. Weng DR, Hsu CS, Gau ML, Chen CH, Li CY: Analysis of the outcomes at baby-friendly hospitals: appraisal in Taiwan. Kaohsiung J Med Sci 2003, 19(1):19-28.

29. Lamb R, Studdert D, Bohmer R, Berwick D, Brennan T: Hospital disclosure practices: results of a national survey. Health Aff 2003, 22(2):73-83.

30. Kozhimannil KB, Valera MR, Adams AS, Ross-Degnan D: The populationlevel impacts of a national health insurance program and franchise midwife clinics on achievement of prenatal and delivery care standards in the Philippines. Health Pol 2009, 92(1):55-64.

31. Valenstein PN, Stankovic AK, Souers RJ, Schneider F, Wagar EA: Document control practices in 120 clinical laboratories. Arch Pathol Lab Med 2009, 133(6):942-949.

32. Longo DR, Brownson RC, Kruse RL: Smoking bans in US hospitals. JAMA 1995, 274(6):488-491.

33. Devers K, Pham H, Liu G: What is driving hospitals' patient-safety efforts? Health Aff 2004, 23(2):103-115.

34. Stradling D, Yu W, Langdorf ML, Tsai F, Kostanian V, Hasso AN, Welbourne SJ, Schooley Y, Fisher MJ, Cramer SC: Stroke care delivery before vs after JCAHO stroke center certification. Neurology 2007, 68(6):469-470.

35. Aiken LH, Buchan J, Ball J, Rafferty AM: Transformative impact of Magnet designation: England case study. J Clin Nurs 2008, 17(24):3330-3337.

36. International Society for Quality in Health Care (ISQua): Accreditation: what is ISQua's International Accreditation Programme?; 2012.

37. Rowe-Murray HJ, Fisher JRW: Baby friendly hospital practices: caesarean section is a persistent barrier to early initiation of breastfeeding. Birth 2002, 29(2):124-131.

38. Timmermans S, Mauck A: The promises and pitfalls of evidence-based medicine. Health Aff 2005, 24(1):18-28.

39. Peña A, Virk S, Shewchuk R, Allison J, Williams O, Kiefe C: Validity versus feasibility for quality of care indicators: expert panel results from the MI-Plus study. Intern J Qual Health Care 2010, 22(3):201-209.

40. Hirsch J, Meyers P, Barr J, Jensen M, Derdeyn C, Manchikanti L: Technical standards and practice guidelines: should we? Why now? Why SNIS? J Neurolntervent Surg 2009, 1:5-7.

41. The Joint Commission: Facts about the National Patient Safety Goals.; 2012. http://www.jointcommission.org/standards_information/npsgs.aspx; access date: 21 August 2012.

42. Shaw C, Kutryba B, Braithwaite J, Bedlicki M, Warunek A: Sustainable healthcare accreditation: messages from Europe in 2009. Intern J Qual Health Care 2010, 22(5):341-350.

43. International Society for Quality in Health Care (ISQua): ISQua's 29th International Conference: scientific programme; 2012. http://www. isquaconference.org/programme; access date: 21 August 2012.

44. Clarke S: Challenges of PHC accreditation:; 2011. http://www. isquaconference. org/images/stories/Steve_Clark.pdf; access date: 21 August 2012.

45. Johnston B: Getting the most out of accreditation.; 2010. http://www.isqua. org/Uploads/Conference/Abstracts/B_JOHNSTON_\%5BCompatibility_Mode \%5D.pdf; access date: 21 August 2012.

46. Greenfield D, Pawsey M, Braithwaite J: Maintaining the standard: what are the options?; 2009. [http://www.isqua.org/Uploads/Conference/Abstracts/ Microsoft_PowerPoint_-_D_Greenfield.pdf]; access date: 21 August 2012.

47. Nicklin W: Accreditation Canada's Qmentum Program: changing survey methodology to enhance value and relevance;; 2009. [http://www.isqua.org/ Uploads/Conference/Abstracts/Microsoft_PowerPoint___combined_\% 5BCompatibility_Mode\%5D.pdf]; access date: 21 August 2012.

48. Bruneau C: Accuracy and the accreditation process.; 2010. access date: 21 August 2012.

49. Karsten Hundborg K, van Ostenberg P: The Danish Healthcare Quality Programme; 2008. http://www.isqua.org/Uploads/Conference/Abstracts/ ISQua08_Accreditation_IKAS_KarstenHundborg.pdf; access date: 21 August 2012.

50. Timmons K: Standards development: an interactive workshop.; 2008. access date: 21 August 2012. 
51. Doets P: Publication Policy NIAZ;; 2008. http://www.isqua.org/Uploads/ Conference/Abstracts/ISQua08_Accreditation_NIAZ_PetraDoets.pdf.pdf; access date: 21 August 2012.

52. Bruneau C: Involving and informing the public through the publication of accreditation results: the French experience.; 2008. http://www.isqua.org/ Uploads/Conference/Abstracts/SQua08_Accreditation_HAS_CharlesBruneau. pdf.pdf; access date: 21 August 2012.

doi:10.1186/1472-6963-12-329

Cite this article as: Greenfield et al:: The standard of healthcare

accreditation standards: a review of empirical research underpinning

their development and impact. BMC Health Services Research 2012 12:329.

\section{Submit your next manuscript to BioMed Central} and take full advantage of:

- Convenient online submission

- Thorough peer review

- No space constraints or color figure charges

- Immediate publication on acceptance

- Inclusion in PubMed, CAS, Scopus and Google Scholar

- Research which is freely available for redistribution 